\title{
Adaptations of Muscle Tissue of Rats Submitted to Aerobic and Anaerobic Physical Training in Different Ergometer Models
}

\author{
Adaptaciones en Tejido Muscular de Ratas Sometidas a Entrenamiento \\ Físico Aeróbico y Anaeróbico en Diferentes Modelos de Ergómetros
}

\begin{abstract}
Guilherme Akio Tamura Ozaki ${ }^{1,2}$; José Carlos Silva Camargo Filho ${ }^{3}$;obson Chacon Castoldi; Thiago Alves Garcia ${ }^{1}$; Paulo Henrique Aleixo ${ }^{3}$; Regina Celi Trindade Camargo ${ }^{3}$; Edna Maria do Carmo ${ }^{3}$ \& William Dias Belangero ${ }^{1}$
\end{abstract}

OZAKI, G. A. T., FILHO, J. C. S. C.; CASTOLDI, R. C.; GARCIA, T. A.; ALEIXO, P. H.; CAMARGO, R. C. T.; CARMO, E. M. \& BELANGERO, W. D. Adaptations of muscle tissue of rats submitted to aerobic and anaerobic physical training in different ergometer models. Int. J. Morphol., 36(4):1161-1167, 2018.

SUMMARY: The objective of the present study was to analyze the effects of four different training models, two aerobic and two anaerobic models, in relation to muscular hypertrophy, by means of morphometric analysis of the muscle cells of the soleus muscle and the extensor digitorum longus muscle (EDL). The animals were divided into five groups, control (C), aerobic training in swimming (ATS), resistance training in water (RTW), aerobic training on a treadmill (ATT), and resistance training in climbing (RTC). The aerobic training was performed at $70 \%$ of the anaerobic threshold for 30 minutes, while the RTW was composed of 3 series of 10 jumps, and the RTC 4 series of climbs, both at $80 \%$ of the maximum load. All training protocols were performed for a total period of 4 weeks, 3 times per week. The diameters of the muscle cells were measured by means of histological slides of the EDL and soleus muscles. For the EDL muscle, there was no difference between the ATS and ATT aerobic training models $(p=0.20)$. However, the RTW presented greater hypertrophy when compared to the RTC ( $\mathrm{p}<0.01$ ). Regarding the soleus muscle, the ATS was responsible for generating greater hypertrophy than the ATT ( $p<0.01$ ). In addition, the RTC was more efficient at producing hypertrophy than the RTW ( $p<0.01$ ). In this way, it was concluded that exercise adaptation was according to exercise type, aerobic or anaerobic, and not to the modality used.

KEY WORDS: Resistance training; Swimming; Hypertrophy; Physical endurance.

\section{INTRODUCTION}

Physical training generally induces anabolic alterations in body tissues. This effect results from the stress caused during its execution and shows variations according to the modality used (Manchado et al., 2006; Castoldi et al., 2013; Ozaki et al., 2014). Aerobic training presents a low intensity and high volume of work (exercise time), while anaerobic or resistance training presents a high intensity and low volume of work (Castoldi et al., 2013).

With regard to muscle tissue, physical training promotes alterations in the structures of muscle cells (sarcoplasm) and in their cellular metabolism (Hood et al., 2011). Due to its plasticity, the skeletal striated muscle may undergo modifications in its microscopical components, with increased cross-section of the muscle fiber, by virtue of the increase in contractile units (actin and myosin filaments) in parallel, resulting in an increase in muscle contraction force; this process is called hypertrophy. In addition, microscopic structures, such as nuclei and mitochondria, may undergo variations in size and number, promoted by increased metabolic demand (Yeo et al., 2008; Castoldi et al., 2013; Ozaki et al., 2016).

It is known that aerobic training increases the ramifications of peripheral vessels, and improves aerobic capacity, promoting greater resistance to metabolic fatigue. In contrast, strength training generates an increase in myofilaments of actin and myosin, which promote muscle contraction force (Jambassi Filho et al., 2010; Teixeira et al., 2011; Castoldi et al., 2013).

\footnotetext{
${ }^{1}$ University of Campinas, UNICAMP. Department of Orthopedics and Traumatology, São Paulo,Brazil.

${ }^{2}$ Paulista University, UNIP, Campus Arçatuba, Araçatuba, São Paulo, Brazil.

${ }^{3}$ Faculty of Science and Technology FCT/UNESP, Campus Presidente Prudente, Department of Physiotherapy, São Paulo - Brazil.

${ }^{4}$ University of Western São Paulo. Department of Physical Education, São Paulo,Brazil.
} 
OZAKI, G. A. T., FILHO, J. C. S. C.; CASTOLDI, R. C.; GARCIA, T. A.; ALEIXO, P. H.; CAMARGO, R. C. T.; CARMO, E. M. \& BELANGERO, W. D. Adaptations of muscle tissue of rats submitted to aerobic and anaerobic physical training in different ergometer models. Int. J. Morphol., 36(4):1161-1167, 2018.

However, there is a scarcity of information regarding the different physical training models and their effects. It is known that muscular adaptation is dependent on the ergometer model used (Manchado et al.; Castoldi et al., 2017a,b). Thus, better understanding of the effects of training in different models and forms of execution, could contribute with researches related to this theme.

Therefore, the objective of the present study was to analyze the effects of four different training models, two aerobic and two anaerobic models, on muscle hypertrophy, by means of morphometric analysis of the muscle cells of the soleus muscle and the extensor digiti I longus muscle (EDIL).

Considering the above, hypothesis $\mathrm{H} 0$ was that there would be no difference between the training models themselves, and hypothesis H1 was that the exercise models would promote different adaptations in muscle tissue.

\section{MATERIAL AND METHOD}

Animals. Forty Wistar rats were used, 150 days of age. The animals were housed in collective cages of five animals each, under controlled conditions of temperature (22 \pm 2 $\left.{ }^{\circ} \mathrm{C}\right)$, humidity $(50 \pm 10 \%)$, and a light/dark cycle of $12 \mathrm{~h}$ (7-19 h), with water and feed provided ad libitum.

Experimental Groups. The animals were divided into five groups according to the independent variables:

- Control $(\mathrm{C}, \mathrm{n}=12)$ : The animals remained in the cages and were submitted to euthanasia in a paired way with the other experimental groups.

- Aerobic Training in Water Group (ATW, n=7): The animals were submitted to the critical load test to determine the training load, and then performed aerobic training in the aquatic environment for 30 minutes, three times a week, with an intensity corresponding to $70 \%$ of the anaerobic threshold with a water temperature of $30^{\circ}$ $\mathrm{C}( \pm 1)$.

- Resistance Training in Water Group (RTW, n=7): The animals were submitted to the 10 Repetitions Maximum (10RM) test to determine the intensity of training, and then performed jump training in the aquatic environment, three times a week, composed of 10 jumps with an overload corresponding to $80 \%$ of 10 Repetition Maximum (10 $\mathrm{RM})$ at a water temperature of $30^{\circ} \mathrm{C}( \pm 1)$.

- Aerobic Training on Treadmill Group (ATT): The animals were submitted to a critical speed test on a treadmill, and then underwent training for 30 minutes, three times a week, with an intensity of $70 \%$ of the anaerobic threshold.
- Resistance Training in Climbing Group (RTC): The animals were submitted to a maximum workload (1 Repetition Maximum) test to determine the training intensity. They then underwent training consisting of 4 climbing series, three times a week, with an intensity corresponding to $80 \%$ of $1 \mathrm{RM}$ ).

\section{Critical Load Test for determination of Anaerobic} Threshold (Lan). The Critical Load (CL) test was used to determine the anaerobic threshold of the animals of the ATS group, and the Critical Speed (CS) test for the animals of the ATT group. For the former, a tank with cylindrical tubes $25 \mathrm{~cm}$ in diameter, with a water depth of $70 \mathrm{~cm}$ was used. For the CS test, a treadmill with individual bays was used.

The tests were carried out at 4 different intensities: $7,9,11$, and $13 \%$ of the body weight for the CL; and 0.9 , $1.2,1.5$, and $1.8 \mathrm{~km} / \mathrm{h}$ for the CS. The intensities were randomized and one was performed each day, with a 24hour interval between sessions, in order to avoid interference from the previous session. In this way, the exercise time of each animal until fatigue was obtained for each intensity. Subsequently the data were multiplied by the inverse of the time limit and plotted on a scatter plot. Subsequently, a trend line (linear) was added which defined the anaerobic threshold (Castoldi et al., 2013).

Maximum load test. In the RTW and RTC groups, a maximum strength test was performed to define the work intensity of each animal. The animals of the RTC group were submitted to the stress on a stairway $(1.1 \times 0.18 \mathrm{~m}, 2$ $\mathrm{cm}$ space between the steps, $80^{\circ}$ inclination), with a load corresponding to $75 \%$ of the body weight of each animal, with $30 \mathrm{~g}$ for each successful climbing attempt. The test was interrupted when the animal failed to climb after three attempts (Leite et al., 2013).

In the RTW group, the same test model was performed, and the animals were submitted to aquatic jumps in a PVC tube $(30 \mathrm{~cm}$ in diameter, $50 \mathrm{~cm}$ in height, with a depth of $38 \mathrm{~cm}$ ), with a load attached to the animal by means of a vest in the region of the torso. This equipment was also used during training (Castoldi et al., 2016).

The animals were submitted to a maximum load test, for which an initial load of $80 \%$ of the animals' body weight was used, and $10 \%$ of the body weight added each new series until the animal was unable to perform the test. Failure to perform the test was determined when the animal failed to complete 10 jumps (10 RM). In this way, the previous successfully performed intensity was assumed as the intensity of $10 \mathrm{RM}$. This test was adapted from the previously proposed climbing model (Leite et al.). 
The training was started $72 \mathrm{~h}$ after the tests, using the same ergometer model. The training sessions were carried out 3 times a week. In the aerobic training, the intensity used was $70 \%$ of the threshold, and anaerobic training was performed at $80 \%$ of maximum intensity.

Sample collection and preparation. Forty-eight hours after the final exercise session, the animals were submitted to euthanasia through anesthetic overdose; ketamine hydrochloride and xylazine hydrochloride intraperitoneally (Garcia et al., 2017). The soleus muscles and the extensor digitorum longus muscle (EDL). were collected from the animals.

Histological Processing of Skeletal Striated Muscle. The muscle tissue was immersed in n-hexane solution and cooled in liquid nitrogen $\left(-190^{\circ} \mathrm{C}\right)$, through the freezing method for unfixed tissues, and later stored in an ultra-low temperature freezer $\left(-75^{\circ} \mathrm{C}\right.$ ) (Camargo Filho et al., 2011). The $5 \mathrm{~mm}$ sections were produced in a cryostat microtome at $-20{ }^{\circ} \mathrm{C}$, collected on slides and then stained with hematoxylin-eosin (HE) for immediate analysis of the minimum muscle cell diameter (Castoldi et al., 2017b).

Optical Microscopy. The sections submitted to HE staining were observed and photomicrographed under a Nikon ${ }^{\circledR} 50 \mathrm{i}$ model microscope, coupled to an Infinity 1 camera. Interactive markers for the determination of muscle fiber cross-sections (AST) were carried out using NIS-Elements D3.0 2- SP7 - Nikon ${ }^{\circledR}$ software. In total, 100 muscle fibers were measured on each slide (Castoldi et al. 2017b).
Statistical analysis. The results were initially analyzed by the Shapiro-Wilk test to verify the Gaussian distribution of the data. As the body weight variable did not present normal distribution, the Wilcoxon test was applied for intra-group evaluation of the differences between the pre and post training periods.

The values of muscle fiber morphometry (soleus and EDL) also did not present normality, so the Kruskal-Wallis test and Dunn's posttest were applied to evaluate the differences between the groups. The analyses were performed using the IBM-SPSS v.22 software, with a significance level of $5 \%$.

\section{RESULTS}

The analysis of the body weight of the animals (Fig. 1) showed a statistically significant difference between the pre and post periods only in the $\mathrm{C}(\mathrm{p}=0.028)$ and ATS groups $(p=0.028)$. Thus, the groups that underwent anaerobic training and the group that performed aerobic treadmill training did not present significant changes in weight during the experimental period.

The morphometry of the muscle fibers of the EDL muscle presented a significant increase in the trained groups (ATW, ATT, RTW, and RTC) in relation to group C ( $p>0.01$ ). The ATW group presented significantly smaller fibers than the RTW and RTC groups (p>0.01). The ATT group also

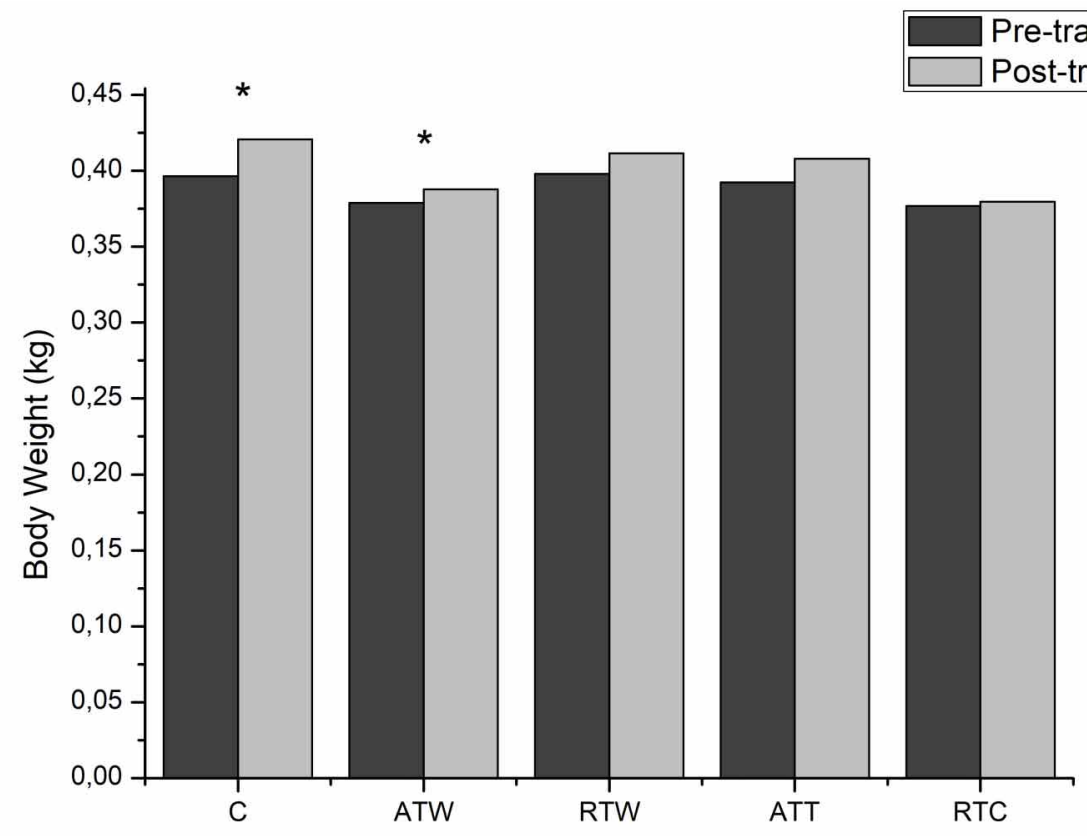

Fig. 1. * Statistically significant difference between the pre- and post-training periods. 


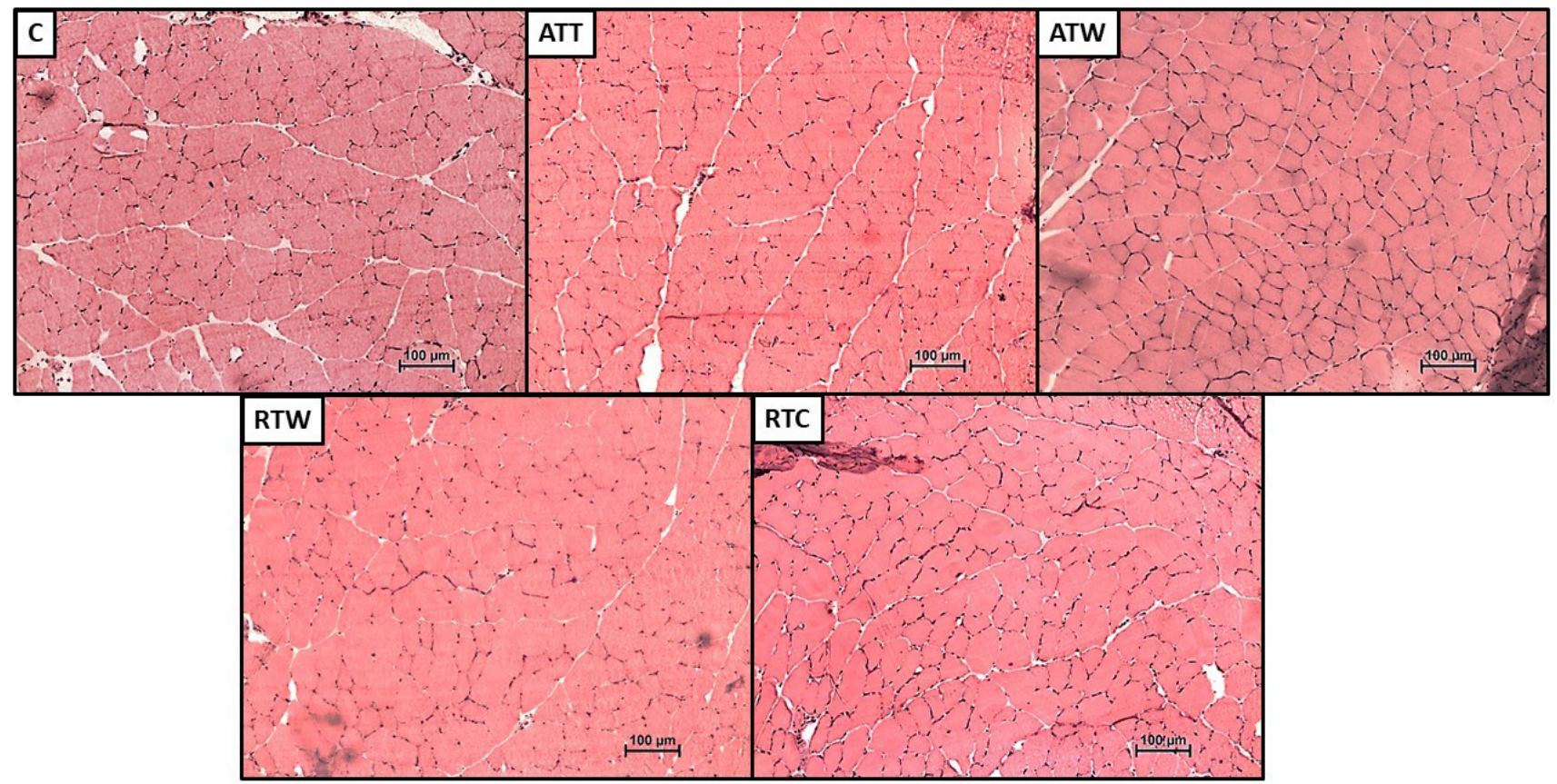

Fig. 2. Cross-sectional image of the EDL muscle, magnification 100x, $100 \mathrm{~mm}$ scale bar. C: Control, ATT: Aerobic Training on Treadmill, ATW: Aerobic Training in Swimming, RTW: Resistance Training in Water, RTC: Resistance Training in Climbing.

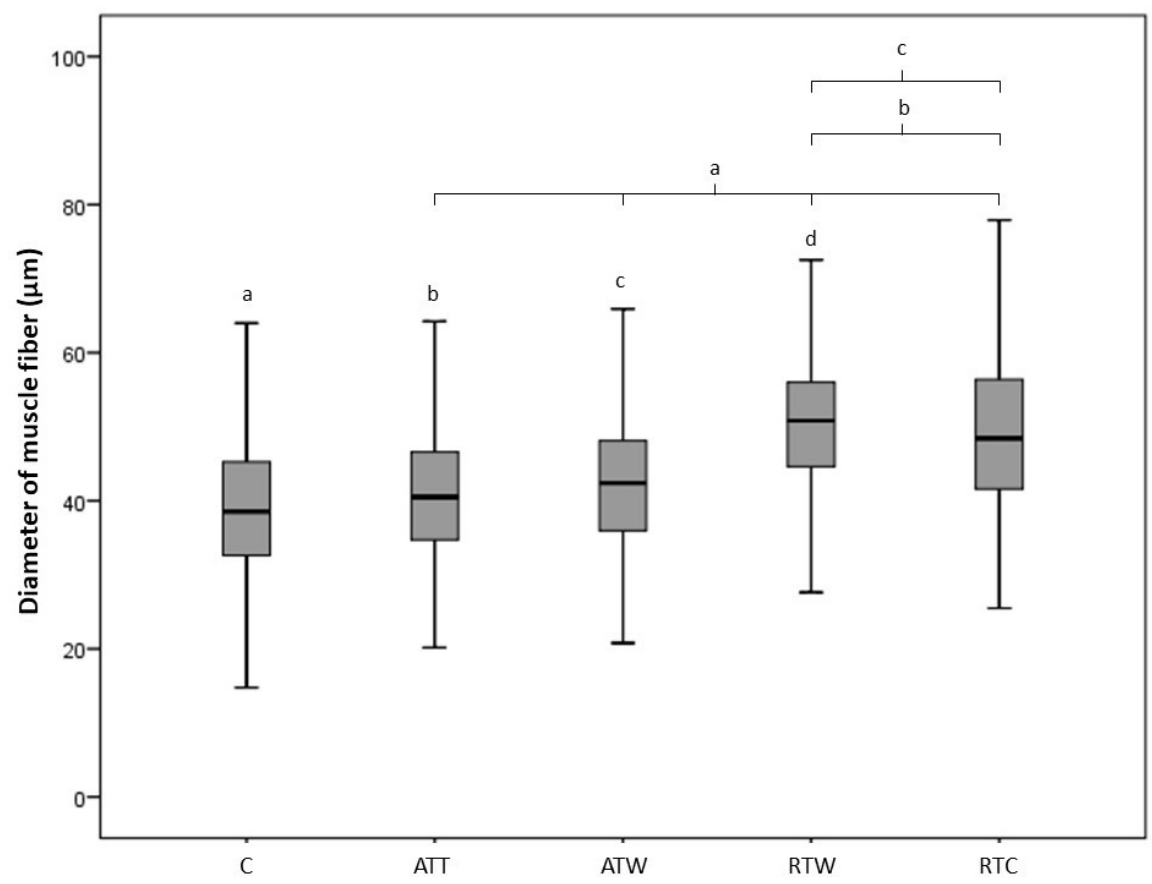

Fig. 3. Box plot with EDL muscle morphometry values. a Significantly different from ATS, ATT, RTW, and RTC. b Significantly different from RTW and RTC. c Significantly different from RTW and RTC. d Significantly different from RTC. C: Control, ATT: Aerobic Training on Treadmill, ATS: Aerobic Training in Swimming, RTW: Resistance Training in Water, RTC: Resistance Training in Climbing. presented smaller fibers than the RTW and RTC groups ( $p>0.01)$. The RTW group demonstrated a significant increase in muscle fibers in relation to the RTC group (Figs. 2 and 3 ).

In relation to the soleus muscle, there was a significant increase in the fibers of all the trained groups (ATS, ATT, RTW, and $\mathrm{RTC}$ ) in relation to group $\mathrm{C}$ $(p>0.01)$. The ATS group presented a significant increase in relation to the ATT and RTW groups, and a significant reduction in relation to the RTC $(p>0.01)$. The ATT group presented a significant reduction in relation to the ATS, RTW, and RTC groups ( $p>0.01$ ), and the RTW group presented a significant reduction in relation to the ATS and RTC groups ( $p>0.01$ ) (Figs. 4 and 5). 


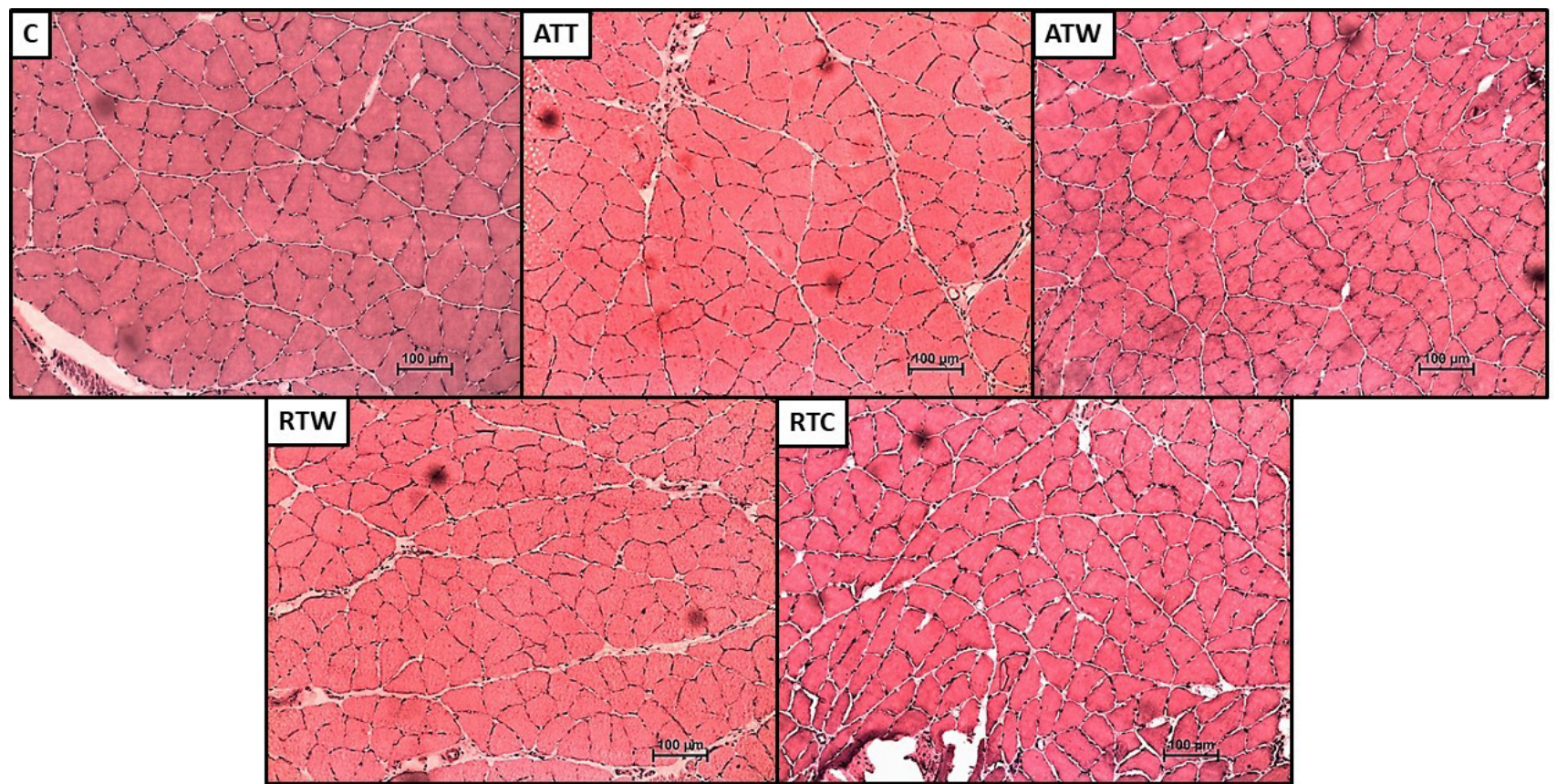

Fig. 4. Cross-sectional image of soleus muscle, 100x magnification, $100 \mathrm{~mm}$ scale bar. C: Control, ATT: Aerobic Training on Treadmill, ATS: Aerobic Training in Swimming, RTW: Resistive Training in Water, RTC: Resistance Training in Climbing.

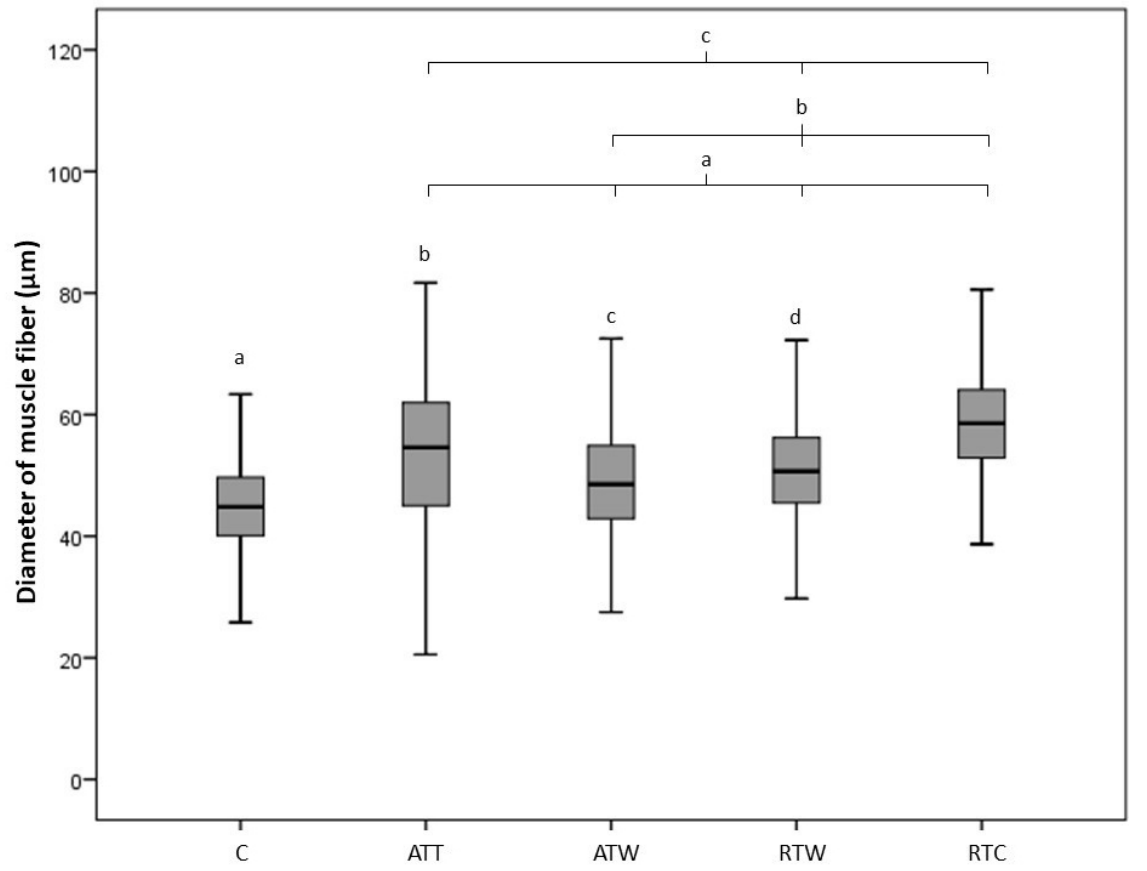

Fig. 5. Box plot with soleus muscle morphometry values. a Significantly different from ATS, ATT, RTW, and RTC. b Significantly different from ATT, RTW, and RTC. c Significantly different from ATS, RTW, and RTC. d Significantly different from ATS and RTC.

\section{DISCUSSION}

The results showed that physical training was effective in promoting muscle hypertrophy in all trained groups in relation to group C. In the EDL muscle there was no difference between the ATS and ATT aerobic training models. However, resistance training with water jumps demonstrated greater hypertrophy when compared to climbing training (RTC). Regarding the soleus muscle, aerobic training in the aquatic environment (ATS) was responsible for generating greater hypertrophy than treadmill training (ATT). In addition, climbing training (RTC) was more efficient for producing hypertrophy than water jumping (RTW).

In the present study, there were differences in hypertrophy between the aerobic and anaerobic training groups, with the groups submitted to 
OZAKI, G. A. T., FILHO, J. C. S. C.; CASTOLDI, R. C.; GARCIA, T. A.; ALEIXO, P. H.; CAMARGO, R. C. T.; CARMO, E. M. \& BELANGERO, W. D. Adaptations of muscle tissue of rats submitted to aerobic and anaerobic physical training in different ergometer models. Int. J. Morphol., 36(4):1161-1167, 2018.

resistance training presenting greater muscular hypertrophy. Both training modalities promote activation of the anabolic pathway in muscle tissue, however of different magnitudes (Ozaki et al., 2016), a fact that may explain the lower muscle hypertrophy in the aerobic training group.

Resistance training promotes micro-injuries in skeletal muscle, with alterations in the cytoskeleton, loss of sarcomeres and structural proteins, and necrosis of muscle fibers, among others (Damas et al., 2018). These changes may be caused by the mechanical stress induced by the training or activation of the calcium degradation pathway and the inflammatory response (Brook et al., 2016; Luciano et al., 2017).

Aerobic training presents the ability to increase cellular organelles, such as mitochondria, improving the energy supply to the muscle (Castoldi et al., 2017a). In addition, other studies (Klemp et al., 2016; Ozaki et al., 2016; Schoenfeld et al., 2016) have demonstrated an anabolic effect through metabolic fatigue, in this way, the hypertrophy pathway would be triggered by this fatigue, not being dependent on the intensity/ load of the exercise (Fink et al., 2016).

Analyzing the differences between the resistance training groups, the RTW group presented greater hypertrophy than the RTC in the soleus muscle. However, in the EDL muscle the training model of the RTC group presented greater muscular hypertrophy. In addition, the animals of the RTW group demonstrated lower values when compared to the animals of the ATS group that performed aerobic training.

Regarding the aerobic training, differences between the ATS and ATT groups were not observed in the soleus muscle. However, in the EDL muscle, the ATS group demonstrated a higher cross-sectional value than the ATT, being even larger than the RTW.

This difference in results can be explained by the difference in the predominance of muscle fiber types: the soleus muscle has a predominance of oxidative fibers, whereas the EDL has a predominance of glycolytic fibers; moreover, there is the interference of the biomechanics of movement, for while the soleus muscle is an ankle extensor, the EDL is a toe extender. In this way, the muscles adapted differently to the training, although both demonstrated greater hypertrophy than the animals that performed the aerobic training (Castoldi et al. 2017b).

As limitations, analysis of protein-specific quantifications of the hypertrophy pathway, such as Insulin Like Growth Factor (IGF-1) and Mammalian Target of Rapamycin (mTOR), could elucidate the pathway of hypertrophy unleashed by the training.

\section{ACKNOWLEDGMENTS.}

Sources of funding: Coordination for the improvement of Higher Education Personnel (CAPES).

\section{CONCLUSION}

It was concluded that all the training models promoted muscle hypertrophy. In addition, in the soleus muscle, resistance training promoted greater hypertrophy than aerobic exercises, however, in the EDL muscle, the RTC and ATS presented greater muscular hypertrophy, in this way the adaptation to the exercise was according to the type of exercise, aerobic or anaerobic, and not the modality used.

OZAKI, G. A. T., FILHO, J. C. S. C.; CASTOLDI, R. C.; GARCIA, T. A.; ALEIXO, P. H.; CAMARGO, R. C. T.; CARMO, E. M. \& BELANGERO, W. D. Adaptaciones en tejido muscular de ratas sometidas a entrenamiento físico aeróbico y anaeróbico en diferentes modelos de ergómetros. Int. J. Morphol., 36(4):1161-1167, 2018.

RESUMEN: El objetivo del estudio fue analizar los efectos de cuatro diferentes modelos de entrenamiento, dos aeróbicos y dos anaeróbicos en la hipertrofia muscular en ratas, a través del análisis morfométrico de las células musculares de los músculos sóleo y extensor largo de los dedos (ELD). Los animales fueran divididos en cinco grupos: control (C), entrenamiento aeróbico en natación (TAN), entrenamiento resistido en medio acuático (TRA), entrenamiento resistido en escalada (TRE) y entrenamiento aeróbico en estera rodante (TRE). Los entrenamientos aeróbicos fueron realizados a $70 \%$ del umbral anaeróbico, durante 30 minutos, en cuanto los TRA fueron realizados por 3 series de 10 saltos y el TRE, 4 series de escaladas, ambos a la intensidad de 80 $\%$ de la carga máxima. Todos los protocolos de entrenamientos fueron realizados tres veces a la semana por un período de 4 semanas. Fueron demarcados los diámetros de las células musculares de los músculos ELD y sóleo por medio de láminas histológicas. En el músculo ELD no se pudo observar diferencia entre los modelos de entrenamiento aeróbico TAN y TAE $(p=0,20)$. Además, el TRA demostró mayor hipertrofia comparado al TRE $(\mathrm{p}<0,01)$. Con relación al músculo sóleo, el TAN fue responsable de generar mayor hipertrofia respecto al TRA $(\mathrm{p}<0,01)$. De este modo es posible concluir que la adaptación depende del tipo de ejercicio, aeróbico o anaeróbico, y no en función de la modalidad utilizada.

PALABRAS CLAVE: Entrenamiento resistido; Natación; Hipertrofia; Resistencia física. 


\section{REFERENCES}

Brook, M. S.; Wilkinson, D. J.; Smith, K. \& Atherton, P. J. The metabolic and temporal basis of muscle hypertrophy in response to resistance exercise. Eur. J. Sport Sci., 16(6):633-44, 2016.

Camargo Filho, J. C. S.; Garcia, B. C.; Kodama, F. Y.; Bonfim, M. R.; Vanderlei, L. C. M.; Ramos, E. M. C.; Camargo, R. C. T.; Padulla, S. A. T. \& Maeda, J. K. Efeitos do exercício aeróbio no músculo esquelético de ratos expostos à fumaça de cigarro. Rev. Bras. Med. Esporte, 17(6):4169, 2011.

Castoldi, R. C.; Aleixo, P. H.; Pereira, A. C. J.; Ferreira, S. R.; Garcia, T. A.; Ozaki, G. A. T.; Koike, T. E.; Júnior, D. A. C. P.; Seraphim, P. M.; Belangero, W. D. \& Camargo Filho, J. C. S. Effects of concurrent training on muscle fibers of wistar rats submitted to standard and hypercaloric diets. Int. J. Morphol., 35(2):637-43, 2017a.

Castoldi, R. C.; Camargo, R. C. T.; Magalhães, A. J. B.; Ozaki, G. A. T.; Kodama, F. Y.; Oikawa, S. M.; Papoti, M. \& Camargo Filho, J. C. S. Concurrent training effect on muscle fibers in Wistar rats. Motriz Rev. Educ. Fís., 19(4):717-23, 2013.

Castoldi, R. C.; Coladello, L. F.; Koike, T. E.; Ozaki, G. A. T.; Magalhães, A. J. B.; Papoti, M.; Camargo Filho, R. C. T. \& Camargo Filho, J. C. Effect of body composition on aerobic capacity of animals submitted to swimming exercise. Rev. Bras. Cineantropom. Desempenho Hum., 18(2):136-42, 2016

Castoldi, R. C.; Ozaki, G. A. T.; Giometti, I. C.; Camargo, R. C. T.; Koike, T. E.; Garcia, T. A.; Camargo Filho, J. C. S. \& Belangero, W. D. Morphometric study of muscle fibers in rats submitted to strength training and growth hormone. Int. J. Morphol., 35(2):472-8, $2017 \mathrm{~b}$.

Damas, F.; Libardi, C. A. \& Ugrinowitsch, C. The development of skeletal muscle hypertrophy through resistance training: the role of muscle damage and muscle protein synthesis. Eur. J. Appl. Physiol., 118(3):485-500, 2018.

Fink, J.; Kikuchi, N.; Yoshida, S.; Terada, K. \& Nakazato, K. Impact of high versus low fixed loads and non-linear training loads on muscle hypertrophy, strength and force development. Springerplus, 5(1):698, 2016.

Garcia, T. A.; Camargo, R. C. T.; Koike, T. E.; Ozaki, G. A. T. ; Castoldi, R. C. \& Camargo Filho, J. C. S. Histological analysis of the association of low level laser therapy and platelet-rich plasma in regeneration of muscle injury in rats. Braz. J. Phys. Ther, 21(6):425-33, 2017.

Hood, M. S.; Little, J. P.; Tarnopolsky, M. A.; Myslik, F. \& Gibala, M. J. Low-volume interval training improves muscle oxidative capacity in sedentary adults. Med. Sci. Sports Exerc., 43(10):1849-56, 2011.

Jambassi Filho, J. C.; Gurjão, A. L. D.; Gonçalves, R.; Barboza, B. H. V. \& Gobbi, S. O Efeito de diferentes intervalos de recuperação entre as séries de treinamento com pesos, na força muscular em mulheres idosas treinadas. Rev. Bras. Med. Esporte, 16(2):112-5, 2010.

Klemp, A.; Dolan, C.; Quiles, J. M.; Blanco, R.; Zoeller, R. F.; Graves, B. S. \& Zourdos, M. C. Volume-equated high- and low-repetition daily undulating programming strategies produce similar hypertrophy and strength adaptations. Appl. Physiol. Nutr. Metab., 41(7):699-705, 2016.

Leite, R. D.; Durigan, R. de C.; de Souza Lino, A. D.; de Souza Campos, M. V.; Souza, M.; Selistre-de-Araújo, H. S.; Bouskela, E. \& Kraemer-Aguiar, L. G. Resistance training may concomitantly benefit body composition, blood pressure and muscle MMP-2 activity on the left ventricle of highfat fed diet rats. Metabolism, 62(10):1477-84, 2013

Luciano, T. F.; Marques, S. O.; Pieri, B. L.; de Souza, D. R.; Araújo, L. V.; Nesi, R. T.; Scheffer, D. L.; Comin, V. H.; Pinho, R. A.; Muller, A. P. \& de Souza, C. T. Responses of skeletal muscle hypertrophy in Wistar rats to different resistance exercise models. Physiol. Res., 66(2):317-23, 2017.

Manchado, F. de B.; Gobatto, C. A.; Contarteze, R. V. L.; Papoti, M. \& Mello, M. A. R. Máxima fase estável de lactato é ergômetro-dependente em modelo experimental utilizando ratos. Rev. Bras. Med. Esporte, 12(5):259-62, 2006.
Ozaki, G. A. T.; Koike, T. E.; Castoldi, R. C.; Garçon, A. A. B.; Kodama, F. Y.; Watanabe, A. Y.; Job, A. E.; Louzada, M. J. Q.; Camargo, R. C. T. \& Camargo Filho, J. C. S. Efeitos da remobilização por meio de exercício físico sobre a densidade óssea de ratos adultos e idosos. Motricidade, 10(3):71-8, 2014

Ozaki, H.; Loenneke, J. P.; Buckner, S. L. \& Abe, T. Muscle growth across a variety of exercise modalities and intensities: Contributions of mechanical and metabolic stimuli. Med. Hypotheses, 88:22-6, 2016.

Schoenfeld, B. J.; Ogborn, D.; Contreras, B.; Cappaert, T.; Silva Ribeiro, A.; Alvar, B. A. \& Vigotsky, A. D. A comparison of increases in volume load over 8 weeks of low-versus high-load resistance training. Asian $J$. Sports Med., 7(2):e29247, 2016.

Teixeira, L.; Ritti-Dias, R. M.; Tinucci, T.; Mion Júnior, D. \& Forjaz, C. L. Post-concurrent exercise hemodynamics and cardiac autonomic modulation. Eur. J. Appl. Physiol., 111(9):2069-78, 2011.

Yeo, W. K.; Paton, C. D.; Garnham, A. P.; Burke, L. M.; Carey, A. L. \& Hawley, J. A. Skeletal muscle adaptation and performance responses to once a day versus twice every second day endurance training regimens. J. Appl. Physiol. (1985), 105(5):1462-70, 2008.

\section{Corresponding author: Guilherme Akio Tamura Ozaki \\ Rua Roberto Simonsen, 305 19060-900 - P. Prudente, SP BRAZIL}

\section{Email: guiozaki@hotmail.com}

Received: 24-04-2018

Accepted: 17-07-2018 